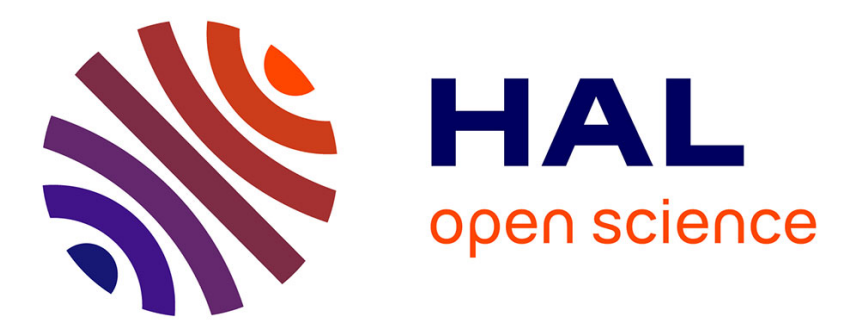

\title{
Patterns, distribution, and determinants of under- and overnutrition among women in Nigeria: a population-based analysis
}

\author{
Olalekan A. Uthman
}

\section{- To cite this version:}

Olalekan A. Uthman. Patterns, distribution, and determinants of under- and overnutrition among women in Nigeria: a population-based analysis. Journal of Public Health, 2009, 17 (5), pp.289-299. 10.1007/s10389-009-0251-z . hal-00535275

\section{HAL Id: hal-00535275 \\ https://hal.science/hal-00535275}

Submitted on 11 Nov 2010

HAL is a multi-disciplinary open access archive for the deposit and dissemination of scientific research documents, whether they are published or not. The documents may come from teaching and research institutions in France or abroad, or from public or private research centers.
L'archive ouverte pluridisciplinaire HAL, est destinée au dépôt et à la diffusion de documents scientifiques de niveau recherche, publiés ou non, émanant des établissements d'enseignement et de recherche français ou étrangers, des laboratoires publics ou privés. 


\title{
Patterns, distribution, and determinants of under- and overnutrition among women in Nigeria: a population-based analysis
}

\author{
Olalekan A. Uthman
}

Received: 10 June 2008 / Accepted: 18 December 2008 /Published online: 20 February 2009

(C) Springer-Verlag 2009

\begin{abstract}
Objective To determine the patterns and determinants of nutritional status among women in Nigeria.

Methods Using a body mass index (BMI) category of 18.5$24.99 \mathrm{~kg} / \mathrm{m} 2$ (normal weight) as the reference, set of univariable and multivariable multinomial logistic regression models were fitted to investigate the independent association between different sociodemographic characteristics and nutritional status. Results were presented in the form of relative risk ratios (RRR) with significance levels and $95 \%$ confidence intervals $(95 \% \mathrm{CI})$.

Results Almost two-thirds of women had BMIs in the normal range. Of the total sample, $14.5 \%$ of subjects were classified as underweight, $14.3 \%$ as overweight and $5.5 \%$ as obese. The youngest women are the most likely subgroup to be thin; one-quarter of women aged 15-19 have a BMI of less than $18.5 \mathrm{~kg} / \mathrm{m}^{2}$. There is significant regional variation, with the prevalence of thinness ranging from $6 \%$ in the north central area to $22 \%$ in the northeast. There was a clear socioeconomic distribution underlying patterns of nutritional status, with women in low socioeconomic positions (SEP) experiencing a greater risk of being underweight and those in high SEPs experiencing the greatest risk of being overweight and obese. Conclusions The results show that women in low SEPs are more likely to be underweight, and women in high SEPs are
\end{abstract}

\footnotetext{
O. A. Uthman

Public Health, Epidemiology and Biostatistics,

Birmingham B15 2TT, UK

O. A. Uthman $(\square)$

Center for Evidence-Based Global Health,

Save the Youth Initiative,

Ilorin, Nigeria

e-mail: a.o.uthman@bham.ac.uk

e-mail: uthlekan@yahoo.com
}

The Public Health Building, The University of Birmingham, more likely to be obese. There is a need for public health programs to promote nutritious food and a healthy lifestyle to address both types of malnutrition at the same time. It will also be important for these programs to be age and region sensitive.

Keywords Malnutrition · Obesity - Socioeconomic status · Nigeria

\section{Background}

Increasingly, health systems in poor countries are simultaneously confronting under- and overnutrition - not only at the national level, but also within households (Caulfield, de Onis, Blossner \& Black 2004). Both under- and overnutrition are linked with a range of adverse health conditions. Body mass index (BMI), a measure to determine the amount of body fat and amount of lean body mass, can be used to determine if a person is underweight, normal weight, overweight or obese (BMI is calculated by dividing a person's weight in kilograms by the square of the person's height in meters, $\mathrm{kg} / \mathrm{m}^{2}$ ). The underweight (defined as having a BMI of less than $18.5 \mathrm{~kg} / \mathrm{m}^{2}$ ) are susceptible to poor maternal and infant health as well as childhood growth problems and compromised mental development. Meanwhile, obesity, defined as a BMI of more than $30 \mathrm{~kg} / \mathrm{m}^{2}$, is associated with such chronic diseases as stroke, hypertension, cardiovascular disease, type- 2 diabetes and certain forms of cancer. Obesity is a serious public health problem with immense health, social and economic implications (Gill King \& Caterson 2005). Obesity is fast approaching cigarette smoking as the major preventable cause of mortality (Gill et al. 2005). In public health terms, the greatest burden of disease arises from obesity-related morbidity (World Health Organization 2000). 
The emergence of the dual burden household is a result of the nutrition transition underway in developing countries that are becoming more prosperous and urbanized. These countries are seeing a decrease in physical activity levels and a shift in diets to include more fats and sugars (Popkin $\&$ Gordon-Larsen 2004). With the globalization of food markets, developing countries have larger quantities of lowcost, high-calorie foods. Influential marketing persuades poorer households to purchase more of these cheap foods (Caballero 2005). The excess energy from these foods may affect adults and children within the same household differently. For example, young children may easily use up the excess energy and still be underweight, while adults may end up gaining weight (Caballero 2005). Physical activity levels and food distribution within the household may also vary from one family member to another, further contributing to the under-/overweight phenomenon (Doak, Adair, Monteiro \& Popkin 2000). Nutritional status can be influenced by both social and biological factors. Previous studies (Cooper et al. 1997; Forrest et al. 2001; Lawoyin et al. 2002; Okesina, Oparinde, Akindoyin \& Erasmus 1999) found that adult women from Nigeria were more likely to be overweight than their male counterparts, suggesting nutritional differentials may be biologically influenced.

The International Obesity Task Force (IOTF) and the World Health Organization (WHO) have identified the emerging patterns of both under- and overnutrition, especially in middleincome and developing countries, as among the top ten future global health problems (Cole, Bellizzi, Flegal, \& Dietz 2000; World Health Organization 2004b). "There is need to simultaneously address the infectious disease epidemics, especially HIV/AIDS, and the potentially serious chronic disease epidemics associated with overweight and obesity" warned the WHO (World Health Organization 2002). However, the specific epidemiological and demographic features of these nutritional changes in developing countries are not fully understood for effective public health interventions (Jinabhai, Taylor \& Sullivan 2005; Mendez, Monteiro \& Popkin 2005) and warrant additional study (Doak et al. 2000). This study used nationally representative data collected between March 2003 and August 2003 in Nigeria to update our knowledge about the prevalence, distribution and determinants of under- and overnutrition among women.

\section{Methods}

\section{Study design}

This cross-sectional study is based on data from the Nigeria 2003 Demography and Health Survey (DHS). The survey was approved by the Ethics Committee of the ORC Macro at Calverton in the USA and by the National Ethics
Committee in the Ministry of Health in Nigeria. All study participants gave informed consent before participation, and all information was collected confidentially.

Sampling technique

Methods used in the Nigeria 2003 DHS have been published elsewhere (National Population Commision \& ORC Macro 2004). Briefly, the survey used a two-stage cluster-sampling technique. The country was stratified into 36 states and the Federal Capital Territory (FCT) of Abuja. Each domain is made up of enumeration areas (EAs) established by a general population and housing census in 1991. The sampling frame was a list of all EAs (clusters). Within each domain, a two-stage sample was selected. The first stage involved selecting 466 clusters (primary sampling units) with a probability proportional to the size, the size being the number of households in the cluster. The second stage involved the systematic sampling of households from the selected clusters. All women aged 15 to 49 years in the selected households were interviewed. The sample was selected using a stratified two-stage cluster design consisting of 365 clusters taken from a list of enumeration areas developed for the 1991 Population Census. A nationally representative probability sample of 7,864 households was then selected from the clusters, in which all women aged 15 to 49 years were eligible to be interviewed.

\section{Data collection}

Data were collected by visiting households and conducting face-to-face interviews to obtain information on demographic characteristics, wealth, nutritional and sexual behavior, among other data, between March and August 2003. The final analytical sample consisted of 6,772 nonpregnant women aged 20-49 who participated in the survey.

\section{Main outcome measure}

Body mass index (BMI), calculated as weight in kilograms divided by height in meters squared $\left(\mathrm{kg} / \mathrm{m}^{2}\right)$, was used as the outcome for this study. Weight was measured by using a solar-powered scale with an accuracy of $\pm 100 \mathrm{~g}$, and height was measured with an adjustable wooden measuring board that is designed to provide accurate measurements (to the nearest $0.1 \mathrm{~cm}$ ) in the context of a developing-country field situation (Mishra 2004). According to WHO conventions (World Health Organization 1995), the following BMI cutoffs were adopted: $<18.5 \mathrm{~kg} / \mathrm{m}^{2}$ (underweight), 18.50 $24.99 \mathrm{~kg} / \mathrm{m}^{2}$ (normal weight), 25-29.9 $\mathrm{kg} / \mathrm{m}^{2}$ (overweight) and $\geq 30 \mathrm{~kg} / \mathrm{m}^{2}$ (obese). 


\section{Covariates}

The study considered four measures of socioeconomic position: wealth index, education, occupation and place of residence. Wealth index was defined in terms of household assets and material possessions, and these have been shown to be reliable and valid measures of household material well-being. Each woman was assigned a standard-of-living score that was based on a linear combination of the scores for different items that were recorded for the household in which the woman resided and that were weighted according to a proportionate possession weighting procedure. The weighted scores were divided into quintiles for the analytic models. The level of education attained was defined as never having been to school, primary and secondary or higher education. Women's current occupation was defined as being currently engaged in white-collar work (e.g., professional and managerial positions, clerical or sales, or generally employed in the service sector), manual or agricultural work (including paid household or domestic work) and not currently participating in the labor force (including those not seeking work, such as homemakers). Place of residence was defined as rural or urban. Other variables were defined as follows: age was stratified into 5-year bands; religion was stratified into Christians, Muslims and others; marital status was defined as never married, currently married, divorced or widowed; tobacco use (yes or no); alcohol use (yes or no); parity (no child, one to four children, five or more children).

\section{Statistical analysis}

The analytical approach included descriptive as well as univariable and multivariable multinomial logistic regression methods. Using a BMI category of $18.5-24.99 \mathrm{~kg} / \mathrm{m}^{2}$ (normal weight) as the reference, a set of logistic regression for underweight, overweight and obese categories was estimated in which each of the categories was contrasted with the reference category. Univariable and multivariable multinomial logistic regression was used to assess the impact of different baseline characteristics over the four groups' BMIs. In the multivariable model, all covariates were entered simultaneously. Results were presented in the form of relative risk ratios (RRR) with significance levels and 95\% confidence intervals $(95 \% \mathrm{CI})$. It is important to note that RRRs in this study only describe an association between characteristics measured at the same time.

Regression diagnostics were used to judge the goodness of fit of the model. They included the tolerance test for multicollinearity, its reciprocal variance inflation factors (VIF), presence of outliers and estimates of adjusted $\mathrm{R}$ square of the regression model. None of the results of the tests provided reasons for concern. Thus, the models provide robust and valid results. Statistical methods for complex survey data, Stata, release 9.2 (Stata Corp., College Station, TX) were used to account for stratification, clustered sampling and weighing to estimate efficient regression coefficients and robust standard errors. Individual weight data analysis was used in this study.

\section{Results}

Descriptive characteristics of the sample for variables considered for the study, tabulated across four categories of body mass index (BMI), are shown in Table 1. The mean BMI of Nigerian women $\left(22.3 \mathrm{~kg} / \mathrm{m}^{2}\right)$ falls well within the internationally accepted normal range (Mei et al. 2002; World Health Organization 1995). Almost two-thirds of women had BMIs in the normal range. Of the total sample, $14.5 \%$ of subjects were classified as underweight, $14.3 \%$ as overweight and $5.5 \%$ as obese. Therefore, $19.3 \%$ of these women had BMIs exceeding the normal weight cutoff point of $25 \mathrm{~kg} / \mathrm{m}^{2}$. The youngest women were the most likely subgroup to be thin; one-quarter of women age 15-19 had a BMI of less than $18.5 \mathrm{~kg} / \mathrm{m}^{2}$. There was significant regional variation, with the prevalence of thinness ranging from $6 \%$ in the north central area to $22 \%$ in the northeast (Table 2).

\section{$\mathrm{BMI}<18.5 \mathrm{~kg} / \mathrm{m}^{2}$ (underweight)}

After controlling for background factors, wealth index, education and occupation remained significantly associated with the risk of being underweight. Compared to the poorest women, the wealthiest women were less likely to be underweight [relative risk ratio (RRR) 0.51 ; 95\% CI (confidence interval) 0.32 to 0.63 ]. Compared to women who had never been to school, those with secondary or higher education were less likely to be underweight (RRR 0.66; $95 \%$ CI 0.51 to 0.87 ). Compared to those not in labor forces, women engaged in manual or agriculture work were less likely to be underweight (RRR 0.69 ; 95\% CI 0.53 to $0.90)$; in addition, those women in non-manual jobs were less likely to be underweight (RRR $0.79 ; 95 \%$ CI 0.64 to 0.96 ).

Among the background factors, increasing age is strongly and negatively associated with being underweight. Independent of the wealth index and other factors, the adjusted effects of alcohol consumption, type of residence and parity were not significant. Women in unions were less likely to be underweight than women who have never married (RRR 0.64; 95\% CI 0.47 to 0.86 ). For religion, Muslim women were more likely to be underweight (RRR 1.66; 95\% CI 1.22 to 2.26) than Christian women. By geographical region, women living in the northeast were more likely to be underweight than those living in the north central area (RRR 3.94; 95\% CI 2.75 to 5.63). 
Table 1 Number and percentage of women in each category of the predictor variables according to body mass index (data from the 2003 Nigeria Demographic and Health Survey)

\begin{tabular}{|c|c|c|c|c|c|c|}
\hline Variable & $\begin{array}{l}\text { Mean } \\
\text { BMI } \\
\mathrm{kg} / \mathrm{m}^{2}\end{array}$ & $\begin{array}{l}\text { Sample size } \\
\text { Number }(\%)\end{array}$ & $\begin{array}{l}\text { Normal } \\
18.50-24.90 \mathrm{~kg} / \mathrm{m}^{2} \\
\text { Number }(\%)\end{array}$ & $\begin{array}{l}\text { Thin } \\
<18.5 \mathrm{~kg} / \mathrm{m}^{2} \\
\text { Number }(\%)\end{array}$ & $\begin{array}{l}\text { Overweight } \\
25-29.99 \mathrm{~kg} / \mathrm{m}^{2} \\
\text { Number }(\%)\end{array}$ & $\begin{array}{l}\text { Obese } \\
\geq 30 \mathrm{~kg} / \mathrm{m}^{2} \\
\text { Number }(\%)\end{array}$ \\
\hline All Nigeria & 23.3 & $6,772(100.0)$ & $4,232(62.7)$ & $982(14.5)$ & $965(14.3)$ & $370(5.5)$ \\
\hline \multicolumn{7}{|l|}{ Age } \\
\hline $15-19$ & 20.5 & 1,597 (23.7) & $1,057(66.1)$ & $376(23.5)$ & $83(5.2)$ & $14(0.9)$ \\
\hline $20-24$ & 21.7 & 1,275 (18.9) & 889 (69.7) & 177 (13.9) & $142(11.1)$ & 37 (2.9) \\
\hline $25-29$ & 22.6 & $1,158(17.2)$ & $736(63.6)$ & 132 (11.4) & $201(17.4)$ & $60(5.2)$ \\
\hline $30-34$ & 23.1 & 797 (11.8) & $496(62.2)$ & 79 (9.9) & $139(17.5)$ & $67(8.5)$ \\
\hline $35-39$ & 23.6 & $705(10.4)$ & $385(54.6)$ & $86(12.3)$ & 147 (20.9) & $70(9.9)$ \\
\hline $40-44$ & 23.5 & $648(9.6)$ & $354(54.7)$ & $82(12.6)$ & $130(20.1)$ & $61(9.4)$ \\
\hline $45-49$ & 23.8 & $571(8.5)$ & $314(55.1)$ & $50(8.8)$ & $121(21.3)$ & $62(10.8)$ \\
\hline \multicolumn{7}{|l|}{ Wealth index } \\
\hline Poorest & 21.13 & $1,233(18.3)$ & $806(65.4)$ & $254(20.6)$ & $103(8.3)$ & $24(2.0)$ \\
\hline Poorer & 21.3 & $1,241(18.4)$ & 838 (67.5) & $212(17.1)$ & $109(8.8)$ & $32(2.6)$ \\
\hline Middle & 22.0 & $1,313(19.5)$ & 857 (65.3) & $200(15.2)$ & $158(12.0)$ & $58(4.4)$ \\
\hline Richer & 22.5 & $1,371(20.3)$ & 876 (63.9) & $175(12.8)$ & $213(15.6)$ & $76(5.5)$ \\
\hline Richest & 24.0 & $1,594(23.6)$ & 854 (53.6) & $141(8.8)$ & $382(23.9)$ & $180(11.3)$ \\
\hline \multicolumn{7}{|l|}{ Education } \\
\hline No education & 21.6 & $2,701(40.0)$ & $1,711(63.3)$ & $509(18.8)$ & $291(10.8)$ & $89(3.3)$ \\
\hline Primary & 22.6 & $1,450(21.5)$ & $936(64.6)$ & $181(12.5)$ & $229(15.8)$ & $84(5.8)$ \\
\hline Secondary/higher & 22.9 & $2,601(38.5)$ & $1,585(60.9)$ & $292(11.2)$ & $445(17.1)$ & $198(7.6)$ \\
\hline \multicolumn{7}{|l|}{ Occupation } \\
\hline Not working & 21.3 & $2,847(42.2)$ & $1,852(65.0)$ & $552(19.4)$ & $253(8.9)$ & $91(3.2)$ \\
\hline White collar & 23.2 & $2,570(38.1)$ & $1,501(58.4)$ & $293(11.4)$ & $492(19.1)$ & $72(8.3)$ \\
\hline Manual/agriculture & 22.6 & $1,334(19.8)$ & $879(65.9)$ & $137(10.3)$ & $220(16.5)$ & $31(5.0)$ \\
\hline \multicolumn{7}{|l|}{ Residence } \\
\hline Rural & 21.8 & $4,370(64.7)$ & $2,860(65.4)$ & $683(15.6)$ & $547(12.5)$ & $151(3.5)$ \\
\hline Urban & 23.2 & $2,382(35.3)$ & $1,372(57.6)$ & $299(12.5)$ & $417(17.5)$ & $219(9.2)$ \\
\hline \multicolumn{7}{|l|}{ Religion } \\
\hline Christian & 23.0 & $3,362(49.8)$ & $2,109(62.7)$ & $326(9.7)$ & $605(18.0)$ & $229(6.8)$ \\
\hline Muslim & 21.6 & $3,297(48.8)$ & $2,063(62.5)$ & $643(19.5)$ & $347(10.5)$ & $139(4.2)$ \\
\hline Other & 21.8 & $86(1.3)$ & $58(67.1)$ & $10(12.1)$ & $12(14.0)$ & $2(2.0)$ \\
\hline \multicolumn{7}{|l|}{ Marital status } \\
\hline Never married & 21.3 & $1,911(28.3)$ & $1,282(67.1)$ & 337 (17.6) & $190(9.9)$ & $37(1.9)$ \\
\hline In union & 22.7 & $4,575(67.8)$ & $2,794(61.1)$ & $616(13.5)$ & $725(15.8)$ & $312(6.8)$ \\
\hline Widowed/divorced & 23.3 & $266(3.9)$ & $156(58.6)$ & $29(10.8)$ & $50(18.7)$ & $21(8.0)$ \\
\hline \multicolumn{7}{|l|}{ Parity } \\
\hline No child & 21.3 & $2,211(32.8)$ & $1,465(66.3)$ & $396(17.9)$ & $220(10.0)$ & $46(2.1)$ \\
\hline One to four children & 22.4 & $2,524(37.4)$ & $1,563(61.9)$ & $353(14.0)$ & $375(14.8)$ & $168(6.7)$ \\
\hline Five children on more & 23.2 & $2,016(29.9)$ & $1,205(59.7)$ & $232(11.5)$ & $370(18.3)$ & $156(7.7)$ \\
\hline \multicolumn{7}{|l|}{ Smoker } \\
\hline No & 22.3 & $6,678(98.1)$ & $4,189(62.7)$ & $971(14.5)$ & $948(14.2)$ & $369(5.5)$ \\
\hline Yes & 22.0 & $74(1.1)$ & $43(58.9)$ & $10(14.5)$ & $16(22.2)$ & $1(1.6)$ \\
\hline \multicolumn{7}{|l|}{ Alcohol consumption } \\
\hline No & 22.1 & $5,810(86.1)$ & $3,683(63.4)$ & $908(15.6)$ & $762(13.1)$ & $280(4.8)$ \\
\hline Yes & 23.7 & $942(13.9)$ & $550(58.3)$ & $74(7.8)$ & $203(21.5)$ & $90(9.6)$ \\
\hline
\end{tabular}


Table 1 (continued)

\begin{tabular}{|c|c|c|c|c|c|c|}
\hline \multicolumn{7}{|c|}{ Body mass index (BMI) $\left(\mathrm{kg} / \mathrm{m}^{2}\right)$} \\
\hline Variable & $\begin{array}{l}\text { Mean } \\
\text { BMI } \\
\mathrm{kg} / \mathrm{m}^{2}\end{array}$ & $\begin{array}{l}\text { Sample size } \\
\text { Number }(\%)\end{array}$ & $\begin{array}{l}\text { Normal } \\
18.50-24.90 \mathrm{~kg} / \mathrm{m}^{2} \\
\text { Number }(\%)\end{array}$ & $\begin{array}{l}\text { Thin } \\
<18.5 \mathrm{~kg} / \mathrm{m}^{2} \\
\text { Number }(\%)\end{array}$ & $\begin{array}{l}\text { Overweight } \\
25-29.99 \mathrm{~kg} / \mathrm{m}^{2} \\
\text { Number }(\%)\end{array}$ & $\begin{array}{l}\text { Obese } \\
\geq 30 \mathrm{~kg} / \mathrm{m}^{2} \\
\text { Number }(\%)\end{array}$ \\
\hline \multicolumn{7}{|l|}{ Region } \\
\hline North central & 23.0 & $1,015(15.0)$ & $697(68.7)$ & $64(6.3)$ & $166(16.3)$ & $59(5.8)$ \\
\hline Northeast & 21.4 & $1,173(17.4)$ & $716(61.0)$ & $258(22.0)$ & $116(9.9)$ & $41(3.5)$ \\
\hline Northwest & 21.5 & $1,756(26.0)$ & $1,112(63.3)$ & $331(18.8)$ & $182(10.4)$ & $70(4.0)$ \\
\hline Southeast & 23.6 & $687(10.2)$ & $379(55.2)$ & $53(7.8)$ & 171 (24.9) & $55(7.9)$ \\
\hline South-south & 23.0 & $1,221(18.1)$ & $765(62.6)$ & $130(10.6)$ & $198(16.2)$ & $95(7.7)$ \\
\hline Southwest & 22.2 & $900(13.3)$ & $564(62.6)$ & $147(16.3)$ & $132(14.6)$ & $52(5.7)$ \\
\hline
\end{tabular}

BMI $25-29.9 \mathrm{~kg} / \mathrm{m}^{2}$ (overweight) and $\geq 30 \mathrm{~kg} / \mathrm{m}^{2}$ (obese)

The associations of the overweight and obese categories with the four socioeconomic position and other background factors were in a similar direction and became more marked for obesity. Compared to poorest women, the wealthiest women were more likely to be overweight (RRR 4.10; 95\% CI 2.32 to 7.23 ) and obese (RRR 4.71; 95\% CI 2.34 to 9.48). The risk of obesity was higher among women with secondary education or higher than women with no education (RRR 2.62; 95\% CI 1.61 to 4.27). Women in the oldest age group (45-49 years) were more likely to be overweight (RRR 5.10; 95\% CI 3.09 to 8.41) and obese (RRR 15.37; 95\% CI 5.78 to 40.92) than the youngest women. Concerning place of residence, living in urban areas was positively associated with a risk of being obese (RRR 1.79; 95\% CI 1.32 to 2.46). Adjusted effect of place of residence on the risk of being overweight reveals that controlling for other factors reverses the direction and alters the significance of the positively and statistically significant unadjusted result. After controlling for other factors, effects of type of occupation, religion, marital status, parity and alcohol consumption on the risk of being overweight and obese are generally small and not statistically significant.

Plotted in Fig. 1 are the predicted probabilities of being obese by age for household quintiles of the standard-ofliving (wealth) index.

There is strong evidence that age modifies the relation between socioeconomic position and BMI. Thus, increasing age seems to increase the risk of being obese for women in all quintiles of the standard-of-living (wealth) index. The risk of being obese is highest for the better-off women at every age. The interaction patterns observed for being overweight were similar to those observed for being obese (Fig. 2).

However, there is little evidence that age modifies the relation between socioeconomic position (SEP) and BMI. As shown in Fig. 3, increasing age seems to reduce the risk of being underweight in all quintiles of the standard-ofliving (wealth) index.

The risk of being underweight is highest for the poorest women at every age. There is no evidence that age modifies the relation between SEP and BMI.

\section{Discussion}

Patterns and distribution of under- and overnutrition

The high prevalence of the overweight in urban areas has been widely acknowledged in the literature (al-Nuaim et al. 1996; Amoah 2003a, 2003b; Malik \& Bakir 2007; Mohan et al. 2004; Sidhu, Kaur \& Prabhjot 2005; Xu et al. 2005); however, these data indicate that the burden in rural areas is also substantial. The study finds that there are far more overweight than underweight among older women in Nigeria. A new report based on data for women younger than 50 in 36 developing countries (Mendez et al. 2005) has found that the numbers of overweight women are increasing at an alarming rate. In ten countries, more than half of the women living in urban areas are overweight, according to the report. In 18 of the countries, more than a fifth of rural women were also overweight.

Overall, these data suggest that being overweight in adults appears to be replacing undernutrition as a public health problem, rather than being added to undernutrition in adults. Global reviews of nutritional status in the developing world have posited that the nutritional transition is characterized by a reduction in the prevalence undernutrition and an increase in the prevalence of overnutrition (World Health Organization 2002). Epidemiologically under- and overnutrition are the products of several risk factors occurring during childhood and adolescence. These range from nutritional deprivation, poor socioeconomic and environmental circumstances and household food insecurity occurring during childhood, to 
Table 2 Crude and adjusted effects (relative risk ratios) of selected risk factors on the risk of underweight, overweight and obesity

\begin{tabular}{|c|c|c|c|c|c|c|}
\hline \multirow[t]{2}{*}{ Variable } & \multicolumn{2}{|l|}{$\mathrm{BMI}<18.5 \mathrm{~kg} / \mathrm{m}^{2}$} & \multicolumn{2}{|c|}{ BMI $25.00-29.99 \mathrm{~kg} / \mathrm{m}^{2}$} & \multicolumn{2}{|l|}{$\mathrm{BMI} \geq 30 \mathrm{~kg} / \mathrm{m}^{2}$} \\
\hline & Crude & Adjusted & Crude & Adjusted & Crude & Adjusted \\
\hline \multicolumn{7}{|l|}{ Age } \\
\hline $15-19$ & 1 & 1 & 1 & 1 & 1 & 1 \\
\hline $20-24$ & $0.56(0.43-0.72)$ & $0.63(0.48-0.83)$ & $2.02(1.51-2.69)$ & $1.74(1.28-2.36)$ & $3.08(1.30-7.30)$ & $2.13(0.87-5.23)$ \\
\hline $25-29$ & $0.50(0.39-0.64)$ & $0.62(0.47-0.81)$ & $3.46(2.38-5.05)$ & $2.72(1.82-4.05)$ & $6.09(3.04-12.18)$ & $3.28(1.34-8.05)$ \\
\hline $30-34$ & $0.45(0.33-0.60)$ & $0.54(0.37-0.78)$ & $3.56(2.55-4.96)$ & $3.26(2.16-4.92)$ & $10.16(5.19-19.87)$ & $7.06(2.90-17.19)$ \\
\hline $35-39$ & $062(0.47-0.82)$ & $0.77(0.54-1.11)$ & $4.84(3.41-6.90)$ & $4.06(2.51-6.56)$ & $13.52(6.78-26.97)$ & $8.41(3.23-21.87)$ \\
\hline $40-44$ & $0.65(0.47-0.88)$ & $0.74(0.50-1.11)$ & $4.64(3.23-6.67)$ & $4.70(2.95-7.50)$ & $12.81(6.94-23.62)$ & $\begin{array}{l}11.80(4.95- \\
28.10)\end{array}$ \\
\hline $45-49$ & $0.44(0.32-0.63)$ & $0.51(0.32-0.81)$ & $4.89(3.31-7.24)$ & $5.10(3.09-8.41)$ & $14.66(7.52-28.58)$ & $\begin{array}{c}15.37(5.78- \\
40.92)\end{array}$ \\
\hline P-value & $<0.001$ & 0.001 & $<0.001$ & $<0.001$ & $<0.001$ & $<0.001$ \\
\hline \multicolumn{7}{|l|}{ Wealth index } \\
\hline Poorest & 1 & 1 & 1 & 1 & 1 & 1 \\
\hline Poorer & $0.80(0.64-1.02)$ & $0.76(0.60-0.99)$ & $1.02(0.63-166)$ & $1.10(0.65-1.86)$ & $1.26(0.68-2.35)$ & $1.25(0.65-2.40)$ \\
\hline Middle & $0.74(0.55-1.00)$ & $0.72(0.55-0.96)$ & $1.44(0.87-2.40)$ & $1.64(0.97-2.76)$ & $2.24(1.22-4.13)$ & $2.12(1.15-3.91)$ \\
\hline Richer & $0.64(0.46-0.86)$ & $0.61(0.45-082)$ & $1.91(1.20-3.04)$ & $2.22(1.32-3.74)$ & $2.86(1.56-5.25)$ & $2.13(1.11-4.06)$ \\
\hline Richest & $0.52(0.37-0.74)$ & $0.53(0.37-0.76)$ & $3.50(2.11-5.81)$ & $4.10(2.32-7.23)$ & $6.99(3.86-12.62)$ & $4.71(2.34-9.48)$ \\
\hline P-value & 0.006 & 0.005 & $<0.001$ & $<0.001$ & $<0.001$ & $<0.001$ \\
\hline \multicolumn{7}{|l|}{ Education } \\
\hline No education & 1 & 1 & 1 & 1 & 1 & 1 \\
\hline Primary & $0.65(0.50-0.84)$ & $0.78(0.61-1.00)$ & $1.44(1.11-1.87)$ & $1.14(0.86-1.51)$ & $1.72(1.13-2.61)$ & $1.54(0.97-2.46)$ \\
\hline Secondary/higher & $0.62(0.49-0.78)$ & $0.66(0.51-0.87)$ & $1.65(1.25-2.18)$ & $1.32(0.94-1.86)$ & $2.40(1.68-3.44)$ & $2.62(1.61-4.27)$ \\
\hline P-value & $<0.001$ & 0.005 & 0.248 & $<0.001$ & $<0.001$ & 0.001 \\
\hline \multicolumn{7}{|l|}{ Occupation } \\
\hline Not working & 1 & 1 & 1 & 1 & 1 & 1 \\
\hline White collar & $0.66(0.54-0.79)$ & $0.79(0.64-0.96)$ & $2.40(1.87-3.08)$ & $1.41(1.09-1.83)$ & $2.90(2.07-4.06)$ & $1.12(0.78-1.61)$ \\
\hline Manual/agriculture & $0.52(0.41-0.68)$ & $0.69(0.53-0.90)$ & $1.83(1.38-2.44)$ & $1.35(0.97-1.89)$ & $1.55(0.96-2.52)$ & $0.92(0.55-1.52)$ \\
\hline P-value & $<0.001$ & 0.008 & $<0.001$ & 0.031 & $<0.001$ & 0.633 \\
\hline \multicolumn{7}{|l|}{ Residence } \\
\hline Rural & 1 & 1 & 1 & 1 & 1 & 1 \\
\hline Urban & $0.91(0.72-1.15)$ & $1.08(0.84-1.39)$ & $1.59(1.15-2.18)$ & $0.98(0.71-1.36)$ & $3.01(2.12-4.27)$ & $1.79(1.30-2.46)$ \\
\hline P-value & 0.441 & 0.534 & 0.005 & 0.923 & $<0.000$ & $<0.001$ \\
\hline \multicolumn{7}{|l|}{ Religion } \\
\hline Christian & 1 & 1 & 1 & 1 & 1 & 1 \\
\hline Muslim & $2.01(1.63-2.50)$ & $1.66(1.22-2.26)$ & $0.59(0.44-0.77)$ & $0.84(0.63-1.12)$ & $0.62(0.44-0.87)$ & $1.15(0.77-1.72)$ \\
\hline P-value & $<0.000$ & 0.001 & $<0.000$ & 0.230 & 0.006 & 0.480 \\
\hline \multicolumn{7}{|l|}{ Marital status } \\
\hline Never married & 1 & 1 & 1 & 1 & 1 & 1 \\
\hline In union & $0.84(0.69-1.02)$ & $0.64(0.47-0.86)$ & $1.75(1.43-2.14)$ & $1.25(0.78-1.97)$ & $3.89(2.35-6.43)$ & $2.19(0.86-5.62)$ \\
\hline Widowed/divorced & $0.70(0.42-1.16)$ & $0.57(0.31-1.03)$ & $2.16(1.35-3.44)$ & $1.26(0.61-2.60)$ & $4.77(2.43-9.35)$ & $2.15(0.75-6.18)$ \\
\hline P-value & 0.125 & 0.013 & $<0.000$ & 0.632 & $<0.000$ & 0.261 \\
\hline \multicolumn{7}{|l|}{ Parity } \\
\hline No child & 1 & 1 & 1 & 1 & 1 & 1 \\
\hline One to four children & $0.84(0.68-1.03)$ & $1.08(0.80-1.46)$ & $1.60(1.29-1.98)$ & $1.06(0.68-1.65)$ & $3.46(2.16-5.52)$ & $1.43(0.53-3.87)$ \\
\hline Five children on more & $0.71(0.58-0.87)$ & $0.90(0.63-1.28)$ & $2.04(1.53-2.73)$ & $1.05(0.63-1.74)$ & $4.16(2.51-6.89)$ & $1.18(0.41-3.44)$ \\
\hline P-value & 0.004 & 0.374 & $<0.000$ & 0.971 & $<0.000$ & 0.496 \\
\hline
\end{tabular}


Table 2 (continued)

\begin{tabular}{|c|c|c|c|c|c|c|}
\hline \multirow[t]{2}{*}{ Variable } & \multicolumn{2}{|l|}{$\mathrm{BMI}<18.5 \mathrm{~kg} / \mathrm{m}^{2}$} & \multicolumn{2}{|c|}{ BMI $25.00-29.99 \mathrm{~kg} / \mathrm{m}^{2}$} & \multicolumn{2}{|l|}{$\mathrm{BMI} \geq 30 \mathrm{~kg} / \mathrm{m}^{2}$} \\
\hline & Crude & Adjusted & Crude & Adjusted & Crude & Adjusted \\
\hline \multicolumn{7}{|c|}{ Alcohol consumption } \\
\hline No & 1 & 1 & 1 & 1 & 1 & 1 \\
\hline Yes & $0.54(0.40-0.74)$ & $0.80(0.59-1.08)$ & $1.78(1.33-2.37)$ & $1.18(0.89-1.59)$ & $2.16(1.56-3.00)$ & $1.39(0.92-2.11)$ \\
\hline P-value & $<0.000$ & 0.154 & $<0.000$ & 0.252 & $<0.000$ & 0.121 \\
\hline \multicolumn{7}{|l|}{ Region } \\
\hline North central & 1 & 1 & 1 & 1 & 1 & 1 \\
\hline Northeast & $3.94(2.75-5.63)$ & $2.82(1.92-4.10)$ & $0.68(0.50-0.92)$ & $0.85(0.58-1.22)$ & $0.67(0.41-1.13)$ & $0.76(0.46-1.27)$ \\
\hline Northwest & $3.25(2.33-4.54)$ & $2.27(1.54-3.34)$ & $0.68(0.50-0.94)$ & $0.84(0.59-1.19)$ & $0.75(0.46-1.22)$ & $0.75(0.47-1.21)$ \\
\hline Southeast & $1.54(0.82-2.90)$ & $1.97(1.02-3.79)$ & $1.90(1.03-3.49)$ & $1.35(0.80-2.30)$ & $1.71(0.79-3.72)$ & $1.15(0.56-2.37)$ \\
\hline South-south & $1.85(1.26-2.74)$ & $2.35(1.50-3.69)$ & $1.09(0.73-1.63)$ & $0.83(0.52-1.33)$ & $1.47(0.86-2.50)$ & $1.03(0.58-1.84)$ \\
\hline Southwest & $2.85(1.91-4.25)$ & $3.30(2.16-5.04)$ & $0.98(0.73-1.31)$ & $0.52(0.37-0.72)$ & $1.09(0.68-1.74)$ & $0.33(0.120-0.56)$ \\
\hline P-value & $<0.000$ & $<0.000$ & 0.003 & 0.004 & 0.024 & 0.001 \\
\hline
\end{tabular}

poor diet and inadequate physical activity associated with overweight and obesity among adolescents (World Health Organization 2004b). There is the possibility that child undernutrition is linked to adult overnutrition, as the fetal origin hypothesis suggests (Mendez et al. 2005; Popkin \& Gordon-Larsen 2004; Popkin, Richards \& Montiero 1996). If so, persistent child undernutrition may well contribute to the burden of overweight in women. To more fully understand how adult nutritional status in Nigeria is changing and influenced by the process of globalization, additional data are needed on the tracking of nutritional status from childhood into adulthood.

Determinants of under- and overnutrition

This study examined the association between socioeconomic position (SEP) and nutritional status among resident

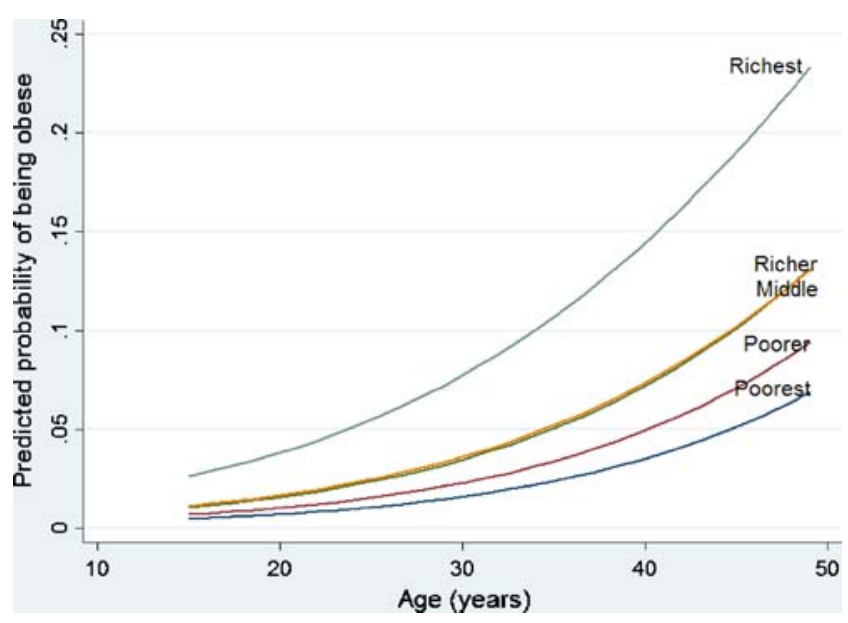

Fig. 1 Plots of predicted probabilities of being obese by age for quintiles of the household standard-of-living index
Nigerian women. This study confirmed previous studies (Dhurandhar \& Kulkarni 1992; Shukla, Gupta, Mehta \& Hebert 2002; Subramanian \& Smith 2006) finding that there is a clear socioeconomic distribution underlying patterns of nutritional status, with women in low SEP experiencing a greater risk of being underweight and those in high SEP experiencing the greatest risk of being overweight and obese. The observed socioeconomic gradients in nutritional status provide clues to the factors that may explain this pattern. Higher income inequality has also been linked to an increased risk of overweight and obesity (adjusted for individual income)(Diez-Roux, Link, \& Northridge 2000), although inconsistent findings have also been reported(Chang \& Christakis 2005). As noted by Subramanian et al. (Subramanian \& Smith 2006), the wealth index, which is directly related to the amount of disposable household income available for food, was the

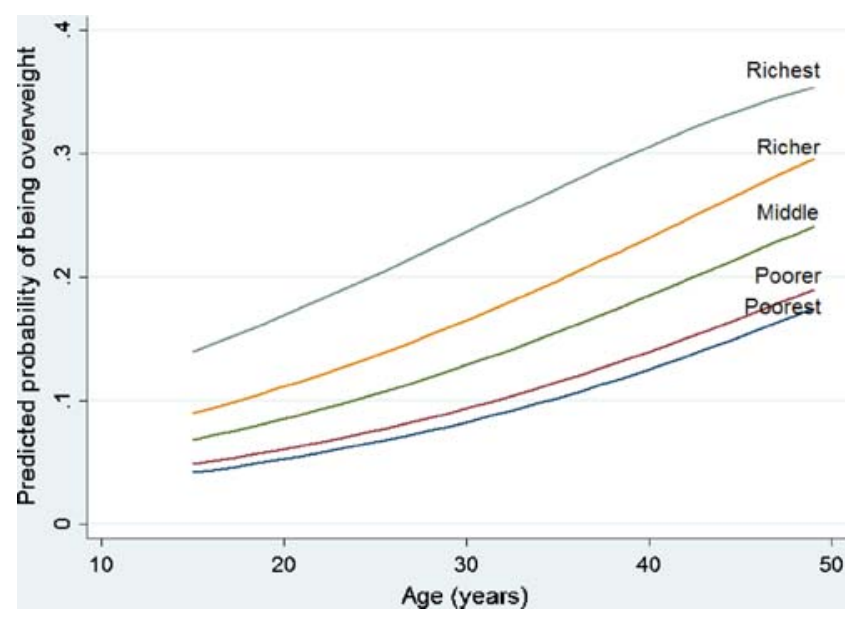

Fig. 2 Plots of predicted probabilities of being overweight by age for quintiles of the household standard-of-living index 


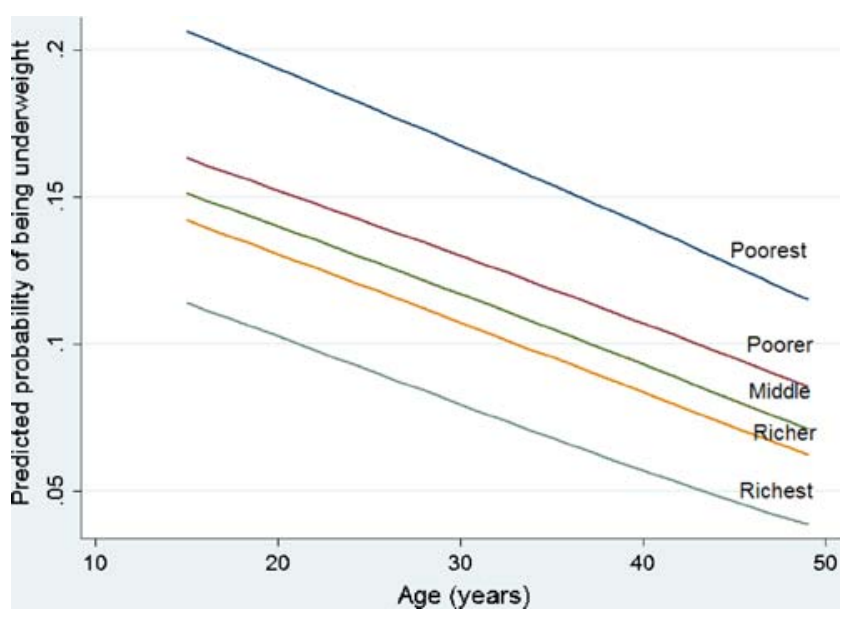

Fig. 3 Plots of predicted probabilities of being underweight by age for quintiles of the household standard-of-living index

single measure most strongly associated with under- and overnutrition. This suggests, perhaps unsurprisingly, that higher expenditure on food is related to greater weight. Manual and agricultural works, which are crude indicators of physical activity, were related to overnutrition in the expected direction, with agricultural and manual workers having a lower prevalence of being overweight. Contrary to previous study (Subramanian \& Smith 2006), agricultural and manual workers were less likely to be underweight.

Interaction effect between the individual standard-ofliving index and women's age for risk of being obese was calibrated to test whether younger women with high SEP had a lowered risk of being obese. The study found no evidence that the risk of obesity might be lower among younger women in the top quintile of the standard-of-living index. The risk of being obese is highest for the better-off women at every age. This study also found significant regional variation for the risk of being underweight, overweight and obese; this finding is intriguing and would benefit from further exploration. With SEP and other potential confounding background factors controlled statistically, women living in the urban area are less likely to be underweight and more likely to be obese. This finding is consistent with earlier studies in Ghana (Amoah 2003a, 2003b) and numerous studies from other parts of the world (al-Nuaim et al. 1996; Malik \& Bakir 2007; Mohan et al. 2004; Sidhu et al. 2005; Xu et al. 2005).

\section{Limitations}

There are several limitations to this study that should be kept in mind when interpreting the results. One important limitation is that DHS surveys do not collect data on household income or expenditure, the traditional indicators used to measure wealth. The assets-based wealth index used here is only a proxy indicator for household economic status, and it does not always produce results similar to those obtained from direct measurements of income and expenditure where such data are available or can be collected reliably (Filmer \& Pritchett 2001; Montgomery, Gragnolati, Burke \& Paredes 2000). Another limitation of the present analysis relates to the use of BMI as the only measure of nutritional status. We defined overweight and underweight by using BMI cutoffs recommended for worldwide use (World Health Organization 1995, 2004a). These cutoffs, established on the basis of the relation of BMI with mortality in Western Europe and North America, also provided measures of increased morbidity risk, although the relation of BMI to morbidity is fairly linear (1994). However, these cutoffs remain controversial (de Onis \& Habicht 1996; Deurenberg-Yap \& Deurenberg 2003; Deurenberg-Yap, Schmidt, van Staveren \& Deurenberg 2000; Deurenberg, Deurenberg-Yap \& Guricci 2002; Gurrici, Hartriyanti, Hautvast \& Deurenberg 1998; Razak et al. 2007; World Health Organization, 2004a), and it is not possible to properly ascertain the magnitude of potential bias derived from the use of these cutoffs. For example, the cutoff of $18.5 \mathrm{~kg} / \mathrm{m}^{2}$ that is used to define underweight likely includes healthy persons, which implies some overestimation of undernutrition. However, there is also some likelihood of underestimation: even though BMIs of $11.0-13.0 \mathrm{~kg} / \mathrm{m}^{2}$ are compatible with survival, there is increased risk of mortality at extremely low BMIs (1994; World Health Organization 1995).

A third limitation is that the survey did not collect direct information on physical activity and total energy intake. Moreover, the study could not control for the extent of use of medical services in connection with underweight and obese, although the set of control variables used in the study includes several measures of SEP, which are typically correlated with access to and use of medical services (Mishra 2004). Finally, cross-sectional data only allow looking at associations; it is impossible to directly assess how the relation between SEP and BMI may change over time (Ball \& Crawford 2005). Prospective cohort studies with better measures of various risk behaviors are needed to better understand the epidemiology of under- and overnutrition.

\section{Policy implications}

The continued trend of overweight and obesity among Nigerian women may result in a chronic disease epidemic as evidenced in the world (Mendez et al. 2005; World Health Organization 2004b). Dual burden households present a unique challenge for public health. Interventions aimed at reducing undernutrition (such as increasing household food supply) often contradict obesity prevention programs. And interventions to reduce overweight or obesity may recommend a reduced fat diet, with adverse 
effects on any underweight members in the same household (Doak et al. 2000). Thus, programs should promote nutritious foods and a healthy lifestyle to address both types of malnutrition at the same time. High-quality dietsthose that consist of sufficient energy and nutrients but are limited in fats, sodium and sugars - benefit those at risk of either under- or overnutrition. Eating more fruits and vegetables helps the overweight while also helping the undernourished. Similarly, an increase in physical activity with adequate energy and protein intake can help build critical muscle mass and contribute to a healthy body composition in both groups (Doak et al. 2000). Regular physical activity is associated with enhanced health and reduced risk of all-cause mortality (Blair et al. 1995; Lee, Hsieh \& Paffenbarger 1995; Lee \& Paffenbarger 2000; Paffenbarger et al. 1993; Paffenbarger et al. 1994). Beyond the effects on mortality, physical activity has many health benefits, including reduced risk of cardiovascular disease (Sesso, Paffenbarger \& Lee 2000; Wannamethee \& Shaper 2001, 2002), ischemic stroke (Gorelick et al. 1999; Hu et al. 2000; Wannamethee \& Shaper 1999), non-insulin dependent (type 2) diabetes (Fulton-Kehoe, Hamman, Baxter \& Marshall 2001; Helmrich, Ragland, Leung \& Paffenbarger 1991; Hu, Leitzmann et al. 2001; Hu, Manson et al. 2001; Kaye, Folsom, Sprafka, Prineas \& Wallace 1991; Pfohl \& Schatz 2001; Uusitupa et al. 1985), colon cancer (Brownson, Chang, Davis \& Smith 1991; Brownson, Zahm, Chang \& Blair 1989; Chow et al. 1993; Dosemeci et al. 1993; Slattery \& Potter 2002; Vetter et al. 1992), osteoporosis (Kohrt, Snead, Slatopolsky \& Birge 1995; Nichols et al. 1994; Rubin et al. 1993), depression (Camacho, Roberts, Lazarus, Kaplan \& Cohen 1991; Fox 1999; Paluska \& Schwenk 2000; Raglin 1990; Ross \& Hayes 1988; Weyerer 1992) and fall-related injuries (Cummings et al. 1990; Farmer et al. 1989; Jaglal, Kreiger \& Darlington 1993, 1995; Meyer, Henriksen, Falch, Pedersen \& Tverdal 1995; Meyer, Tverdal, \& Falch 1993). The WHO strategy 2002 could serve as a basis for design for such interventions, but would need to be highly selective in the targeting, which should be gender, age and regional specific (World Health Organization, 2002).

However, public health programs alone are not enough. Poor households are often unable to afford healthier foods. Governments therefore must play a key role in monitoring and regulating the food market. By alleviating price constraints, government intervention-for example, in the form of food subsidies - can improve access to healthy foods.

\section{Conclusions}

This study provides information on the prevalence and risk factors for nutritional status among Nigerian women. The results shows that women in low socioeconomic positions (SEP) are more likely to be underweight, and women in high SEP are more likely to be obese. There is a need for public health programs to promote nutritious food and a healthy lifestyle to address both types of malnutrition at the same time. It will also be important for these programs to be age- and region-sensitive.

Acknowledgements The author is grateful to Measure DHS for providing Nigeria 2003 DHS data.

Conflict of interest The author confirms that there are no any relevant associations that might pose a conflict of interest.

Authors' contributions OAU conceived the study, extracted the data, did the analyses and interpretation and wrote the first and final draft of the manuscript.

\section{References}

al-Nuaim AR, al-Rubeaan K, al-Mazrou Y, al-Attas O, al-Daghari N, Khoja T (1996) High prevalence of overweight and obesity in Saudi Arabia. Int J Obes Relat Metab Disord 20(6):547-552

Amoah AG (2003a) Obesity in adult residents of Accra, Ghana. Ethn Dis 13(2 Suppl 2):S97-S101

Amoah AG (2003b) Sociodemographic variations in obesity among Ghanaian adults. Public Health Nutr 6(8):751-757

Ball K, Crawford D (2005) Socioeconomic status and weight change in adults: a review. Soc Sci Med 60(9):1987-2010

Blair SN, Kohl HW 3rd, Barlow CE, Paffenbarger RS Jr, Gibbons LW, Macera CA (1995) Changes in physical fitness and all-cause mortality. A prospective study of healthy and unhealthy men. JAMA 273(14):1093-1098

Brownson RC, Zahm SH, Chang JC, Blair A (1989) Occupational risk of colon cancer. An analysis by anatomic subsite. Am J Epidemiol 130(4):675-687

Brownson RC, Chang JC, Davis JR, Smith CA (1991) Physical activity on the job and cancer in Missouri. Am J Public Health 81(5):639-642

Caballero B (2005) A nutrition paradox-underweight and obesity in developing countries. N Engl J Med 352(15):1514-1516

Camacho TC, Roberts RE, Lazarus NB, Kaplan GA, Cohen RD (1991) Physical activity and depression: evidence from the Alameda County Study. Am J Epidemiol 134(2):220-231

Caulfield LE, de Onis M, Blossner M, Black RE (2004) Undernutrition as an underlying cause of child deaths associated with diarrhea, pneumonia, malaria, and measles. Am J Clin Nutr 80(1):193198

Chang VW, Christakis NA (2005) Income inequality and weight status in US metropolitan areas. Soc Sci Med 61(1):83-96

Chow WH, Dosemeci M, Zheng W, Vetter R, McLaughlin JK, Gao YT et al (1993) Physical activity and occupational risk of colon cancer in Shanghai, China. Int J Epidemiol 22(1):23-29

Cole TJ, Bellizzi MC, Flegal KM, Dietz WH (2000) Establishing a standard definition for child overweight and obesity worldwide: international survey. BMJ 320(7244):1240-1243

Cooper R, Rotimi C, Ataman S, McGee D, Osotimehin B, Kadiri S et al (1997) The prevalence of hypertension in seven populations of west African origin. Am J Public Health 87(2):160-168

Cummings SR, Black DM, Nevitt MC, Browner WS, Cauley JA, Genant HK et al (1990) Appendicular bone density and age 
predict hip fracture in women. The Study of Osteoporotic Fractures Research Group. JAMA 263(5):665-668

de Onis M, Habicht JP (1996) Anthropometric reference data for international use: recommendations from a World Health Organization Expert Committee. Am J Clin Nutr 64(4):650-658

Deurenberg-Yap M, Deurenberg P (2003) Is a re-evaluation of WHO body mass index cut-off values needed? The case of Asians in Singapore. Nutr Rev 61(5 Pt 2):S80-S87

Deurenberg-Yap M, Schmidt G, van Staveren WA, Deurenberg P (2000) The paradox of low body mass index and high body fat percentage among Chinese, Malays and Indians in Singapore. Int J Obes Relat Metab Disord 24(8):1011-1017

Deurenberg P, Deurenberg-Yap M, Guricci S (2002) Asians are different from Caucasians and from each other in their body mass index/body fat per cent relationship. Obes Rev 3(3):141-146

Dhurandhar NV, Kulkarni PR (1992) Prevalence of obesity in Bombay. Int J Obes Relat Metab Disord 16(5):367-375

Diez-Roux AV, Link BG, Northridge ME (2000) A multilevel analysis of income inequality and cardiovascular disease risk factors. Soc Sci Med 50(5):673-687

Doak CM, Adair LS, Monteiro C, Popkin BM (2000) Overweight and underweight coexist within households in Brazil, China and Russia. J Nutr 130(12):2965-2971

Dosemeci M, Hayes RB, Vetter R, Hoover RN, Tucker M, Engin K et al (1993) Occupational physical activity, socioeconomic status, and risks of 15 cancer sites in Turkey. Cancer Causes Control 4(4):313-321

Farmer ME, Harris T, Madans JH, Wallace RB, Cornoni-Huntley J, White LR (1989) Anthropometric indicators and hip fracture. The NHANES I epidemiologic follow-up studyx. J Am Geriatr Soc 37(1):9-16

Filmer D, Pritchett LH (2001) Estimating wealth effects without expenditure data-or tears: an application to educational enrollments in states of India. Demography 38(1):115-132

Forrest KY, Bunker CH, Kriska AM, Ukoli FA, Huston SL, Markovic N (2001) Physical activity and cardiovascular risk factors in a developing population. Med Sci Sports Exerc 33(9):1598-1604

Fox KR (1999) The influence of physical activity on mental wellbeing. Public Health Nutr 2(3A):411-418

Fulton-Kehoe D, Hamman RF, Baxter J, Marshall J (2001) A casecontrol study of physical activity and non-insulin dependent diabetes mellitus (NIDDM). the San Luis Valley Diabetes Study. Ann Epidemiol 11(5):320-327

Gill T, King L, Caterson I (2005) Obesity prevention: necessary and possible. A structured approach for effective planning. Proc Nutr Soc 64(2):255-261

Gorelick PB, Sacco RL, Smith DB, Alberts M, Mustone-Alexander L, Rader D et al (1999) Prevention of a first stroke: a review of guidelines and a multidisciplinary consensus statement from the National Stroke Association. JAMA 281(12):1112-1120

Gurrici S, Hartriyanti Y, Hautvast JG, Deurenberg P (1998) Relationship between body fat and body mass index: differences between Indonesians and Dutch Caucasians. Eur J Clin Nutr 52 (11):779-783

Helmrich SP, Ragland DR, Leung RW, Paffenbarger RS Jr (1991) Physical activity and reduced occurrence of non-insulindependent diabetes mellitus. N Engl J Med 325(3):147-152

Hu FB, Stampfer MJ, Colditz GA, Ascherio A, Rexrode KM, Willett WC et al (2000) Physical activity and risk of stroke in women. JAMA 283(22):2961-2967

Hu FB, Leitzmann MF, Stampfer MJ, Colditz GA, Willett WC, Rimm EB (2001) Physical activity and television watching in relation to risk for type 2 diabetes mellitus in men. Arch Intern Med 161 (12): $1542-1548$

Hu FB, Manson JE, Stampfer MJ, Colditz G, Liu S, Solomon CG et al (2001) Diet, lifestyle, and the risk of type 2 diabetes mellitus in women. N Engl J Med 345(11):790-797
Jaglal SB, Kreiger N, Darlington G (1993) Past and recent physical activity and risk of hip fracture. Am J Epidemiol 138(2):107-118

Jaglal SB, Kreiger N, Darlington GA (1995) Lifetime occupational physical activity and risk of hip fracture in women. Ann Epidemiol 5(4):321-324

Jinabhai CC, Taylor M, Sullivan KR (2005) Changing patterns of under- and over-nutrition in South African children-future risks of non-communicable diseases. Ann Trop Paediatr 25(1):3-15

Kaye SA, Folsom AR, Sprafka JM, Prineas RJ, Wallace RB (1991) Increased incidence of diabetes mellitus in relation to abdominal adiposity in older women. J Clin Epidemiol 44(3):329-334

Kohrt WM, Snead DB, Slatopolsky E, Birge SJ Jr (1995) Additive effects of weight-bearing exercise and estrogen on bone mineral density in older women. J Bone Miner Res 10(9):1303-1311

Lawoyin TO, Asuzu MC, Kaufman J, Rotimi C, Owoaje E, Johnson L et al (2002) Prevalence of cardiovascular risk factors in an African, urban inner city community. West Afr J Med 21(3):208-211

Lee IM, Paffenbarger RS Jr (2000) Associations of light, moderate, and vigorous intensity physical activity with longevity. The Harvard Alumni Health Study. Am J Epidemiol 151(3):293-299

Lee IM, Hsieh CC, Paffenbarger RS Jr (1995) Exercise intensity and longevity in men. The Harvard Alumni Health Study. JAMA 273 (15): $1179-1184$

Malik M, Bakir A (2007) Prevalence of overweight and obesity among children in the United Arab Emirates. Obes Rev 8(1):15-20

Mei Z, Grummer-Strawn LM, Pietrobelli A, Goulding A, Goran MI, Dietz WH (2002) Validity of body mass index compared with other body-composition screening indexes for the assessment of body fatness in children and adolescents. Am J Clin Nutr 75 (6):978-985

Mendez MA, Monteiro CA, Popkin BM (2005) Overweight exceeds underweight among women in most developing countries. Am J Clin Nutr 81(3):714-721

Meyer HE, Tverdal A, Falch JA (1993) Risk factors for hip fracture in middle-aged Norwegian women and men. Am J Epidemiol 137 (11):1203-1211

Meyer HE, Henriksen C, Falch JA, Pedersen JI, Tverdal A (1995) Risk factors for hip fracture in a high incidence area: a casecontrol study from Oslo, Norway. Osteoporos Int 5(4):239-246

Mishra V (2004) Effect of obesity on asthma among adult Indian women. Int J Obes Relat Metab Disord 28(8):1048-1058

Mohan B, Kumar N, Aslam N, Rangbulla A, Kumbkarni S, Sood NK et al (2004) Prevalence of sustained hypertension and obesity in urban and rural school going children in Ludhiana. Indian Heart J 56(4):310-314

Montgomery MR, Gragnolati M, Burke KA, Paredes E (2000) Measuring living standards with proxy variables. Demography 37(2):155-174

National Population Commision, \& ORC Macro (2004) Nigeria demographic and health survey 2003. Calverton, Maryland

Nichols DL, Sanborn CF, Bonnick SL, Ben-Ezra V, Gench B, DiMarco NM (1994) The effects of gymnastics training on bone mineral density. Med Sci Sports Exerc 26(10):1220-1225

Okesina AB, Oparinde DP, Akindoyin KA, Erasmus RT (1999) Prevalence of some risk factors of coronary heart disease in a rural Nigerian population. East Afr Med J 76(4):212-216

Paffenbarger RS Jr, Hyde RT, Wing AL, Lee IM, Jung DL, Kampert JB (1993) The association of changes in physical-activity level and other lifestyle characteristics with mortality among men. $\mathrm{N}$ Engl J Med 328(8):538-545

Paffenbarger RS Jr, Kampert JB, Lee IM, Hyde RT, Leung RW, Wing AL (1994) Changes in physical activity and other lifeway patterns influencing longevity. Med Sci Sports Exerc 26 (7):857-865

Paluska SA, Schwenk TL (2000) Physical activity and mental health: current concepts. Sports Med 29(3):167-180 
Pfohl M, Schatz H (2001) Strategies for the prevention of type 2 diabetes. Exp Clin Endocrinol Diabetes 109 Suppl 2:S240-S249

Popkin BM, Gordon-Larsen P (2004) The nutrition transition: worldwide obesity dynamics and their determinants. Int J Obes Relat Metab Disord 28 Suppl 3:S2-S9

Popkin BM, Richards MK, Montiero CA (1996) Stunting is associated with overweight in children of four nations that are undergoing the nutrition transition. J Nutr 126(12):3009-3016

Raglin JS (1990) Exercise and mental health. Beneficial and detrimental effects. Sports Med 9(6):323-329

Razak F, Anand SS, Shannon H, Vuksan V, Davis B, Jacobs R et al (2007) Defining obesity cut points in a multiethnic population. Circulation 115(16):2111-2118

Ross CE, Hayes D (1988) Exercise and psychologic well-being in the community. Am J Epidemiol 127(4):762-771

Rubin K, Schirduan V, Gendreau P, Sarfarazi M, Mendola R, Dalsky G (1993) Predictors of axial and peripheral bone mineral density in healthy children and adolescents, with special attention to the role of puberty. J Pediatr 123(6):863-870

Sesso HD, Paffenbarger RS Jr, Lee IM (2000) Physical activity and coronary heart disease in men: The Harvard Alumni Health Study. Circulation 102(9):975-980

Shetty PS, James WPT (1994) Body mass index - a measure of chronic energy deficiency in adults. FAO Food and Nutrition Paper 56: FAO, Rome, Italy

Shukla HC, Gupta PC, Mehta HC, Hebert JR (2002) Descriptive epidemiology of body mass index of an urban adult population in western India. J Epidemiol Community Health 56(11):876-880

Sidhu S, Kaur A, Prabhjot (2005) Prevalence of overweight and obesity among urban and rural adult females of Punjab. Anthropol Anz 63(3):341-345

Slattery ML, Potter JD (2002) Physical activity and colon cancer: confounding or interaction? Med Sci Sports Exerc 34(6):913-919

Subramanian SV, Smith GD (2006) Patterns, distribution, and determinants of under- and overnutrition: a population-based study of women in India. Am J Clin Nutr 84(3):633-640
Uusitupa M, Siitonen O, Pyorala K, Aro A, Hersio K, Penttila I et al (1985) The relationship of cardiovascular risk factors to the prevalence of coronary heart disease in newly diagnosed type 2 (non-insulin-dependent) diabetes. Diabetologia 28 (9):653-659

Vetter R, Dosemeci M, Blair A, Wacholder S, Unsal M, Engin K et al (1992) Occupational physical activity and colon cancer risk in Turkey. Eur J Epidemiol 8(6):845-850

Wannamethee SG, Shaper AG (1999) Physical activity and the prevention of stroke. J Cardiovasc Risk 6(4):213-216

Wannamethee SG, Shaper AG (2001) Physical activity in the prevention of cardiovascular disease: an epidemiological perspective. Sports Med 31(2):101-114

Wannamethee SG, Shaper AG (2002) Physical activity and cardiovascular disease. Semin Vasc Med 2(3):257-266

Weyerer S (1992) Physical inactivity and depression in the community. Evidence from the Upper Bavarian Field Study. Int J Sports Med 13(6):492-496

World Health Organization (1995) Physical status: the use and interpretation of anthropometry. Report of a WHO Expert Committee. World Health Organ Tech Rep Ser 854:1-452

World Health Organization (2000) Obesity: preventing and managing the global epidemic. Report of a WHO consultation. World Health Organ Tech Rep Ser 894, i-xii, 1-253

World Health Organization (2002) The world health report 2002: reducing risks, promoting healthy life: WHO. Geneva, Switzerland

World Health Organization (2004a) Appropriate body-mass index for Asian populations and its implications for policy and intervention strategies. Lancet 363(9403):157-163

World Health Organization (2004b) Global strategy on diet, physical activity and health: who. Geneva, Switzerland

Xu F, Yin XM, Zhang M, Leslie E, Ware R, Owen N (2005) Family average income and body mass index above the healthy weight range among urban and rural residents in regional Mainland China. Public Health Nutr 8(1):47-51 